\title{
Banyumas Proverbs as the Reflection of its Local Wisdom
}

\author{
Agus Sapto Nugroho ${ }^{1}$, M. Riyanton ${ }^{2}$, Mustasyfa Thabib Kariadi $^{3}$ \\ \{agussaptonugroho57@gmail.com ${ }^{1}$, muhammadriyanton@gmail.com ${ }^{2}$, \\ mtkariadi18@gmail.com ${ }^{3}$ )
}

Faculty of Humanities, Jenderal Soedirman University, Indonesia,

\begin{abstract}
This research aimed at describing and analyzing the value of local wisdom in Javanese culture contained in Banyumas proverbs. This research was classified into a descriptive qualitative study with ethno-linguistic research approach as the information was carefully described and well analyzed. This research employed a single case study specifically conducted on one characteristic and one target (subject), that is, proverbs in Banyumas Regency. The research data were collected from several informants, and documents using direct participatory observation, interviews, and document analysis using purposive sampling technique. The results of the study showed that Javanese proverbs reflecting behaviors symbolized by the puppet character of Bawor include patient in accepting fate (sabar, nerima), noble (ksatria), agile (cekatan), and frankly speaking (cablaka).
\end{abstract}

Keywords: Proverbs, Local Wisdom

\section{Introduction}

Culture has its own peculiarities and reflects different values of life. Therefore it is normal when talking about a particular community or ethnicity, the first question arises always has to do with their customs, lifestyle, and the way they communicate. This study aims to examine the culture and language domain, especially the local wisdom in the form of knowledge and practices commonly used by the local community to solve problems in a good and correct manner.

Culture refers to a set of practices, codes, and values that labels a group. Cultural discussion cannot be separated from the way it is held and communication media cannot be separated from the language position as a medium of expression of human mind reflection. So, language is a medium and reflection of culture. By means of language, human beings can adjust themselves to customs, behavior, public manners, and at the same time easily blend themselves with all forms of society.

Java-Banyumas proverbs is one of language styles in the form of a traditional expression or figure language in the form of sentences or groups of words that are solid, concise, simple and containing norms, values, advice, comparisons, parables, principles and rules of behavior. In Javanese culture, Banyumas proverbs is widely used to convey certain local wisdom messages or values. Javanese language refers to the definition of local wisdom as a tool of knowledge and practices that can be used to solve problems faced in a good and correct 
manner (Ahimsa 2007:

32). Moreover, Pluger (2015) stated that proverbs material has two basic categories: nonopposition proverbs / equalizing identification; and a contrasting opposition sayings. Further research by Bernard and Fernandez (2012) dealing with Caribbean proverbs described in their analysis that the use of proverbs as a cultural metaphor can help build cross-cultural empathy. Ideally this approach would produce cross-cultural learners who showed higher levels of cultural competence and leadership skills. Globalization and modernization in the 21st century have created a context in which cultural competence is very important for social and economic development policy.

Based on the background above, ethnographic research in the field of cultural understanding reflected in proverbs is very important in relation to understanding the personality and values of local culture. Ethnic groups that have a distinctive proverbs full of diversity need a deeper understanding, especially to understand the intent, meaning, and values contained in it. The scope of this research is the proverbs contained and used in the Java-Banyumas language, identifying the functions of using the Java-Banyumas proverbs, and explore local values in Javanese culture contained in the Banyumas Javanese proverbs.

\section{Research Method}

This research was a descriptive qualitative research. Descriptive method was used to describe the local wisdom of the Banyumas proverbs. The main data source in qualitative research were in the form words, the rest were additional data such as documents and others (Moleong, 1993: 112). The population in this study was the people in Banyumas Regency, while the sample was a portion of the representing population used as the object of direct research. (Subroto, 1992: 36). This research was descriptive qualitative by utilizing ethnographic methods with a model of ethnics analysis (Spradley, 1997: 19). Sources of data and research data includedprimary and secondary in the form of verbal expressions (Banyumas proverbs) and nonverbal (contexts and cultural events) containing local wisdom in the context of Javanese language and culture in Banyumas Regency using purposive sampling technique besides using snow-ball sampling; this process was continuously employed to get complete data (Sutopo, 2006: 45-46). (1) Participant observation (Spradley, 1997: 106) and (2) in-depht-interviewing techniques were used to collect the data with selected informants to interpret Javanese proverbs in Banyumas Regency. Ethnoscience model analysis especially the taxonomic, componential, and domain analyzes relevant to the analysis based on cultural themes (Spradley, 1997: 120). Data validity was taken by triangulation technique, key informant review and member check (Sutopo, 2006: 92)

\section{Result and Discusion}

Proverbs are defined as sentences or fragments of sentences that have frozen their form, meaning, and function in a society, is hereditary, used for decorating essays or conversations, reinforcing intentions, giving advice, teaching or living guidelines including thimbles, proverbs, parables, similarities and quotations (Harimurti Kridalaksana, 2001: 169). Proverbs occupy an important place among folklore, greetings, puzzles, jokes, curses, songs and fables, but are quite complicated and instructive. Proverbs are often regarded as obsolete 
language, have extensive use, or expresses popular attitudes. Similar to other folklore expressions, proverbs is an integral part of the cultural landscape. In this case, proverbs can be considered as an embedded field of knowledge (Jha, 2014). follows:

This study examined the proverbs that exist in Banyumas and for the results are as

Banyumas proverbs reflecting the behavior (character) arousing the spirit of nationalism, for example the Banyumas proverbs sada seler kanggo nyapu sajagad; "one palm-leaf rib used to sweep the whole world" which could be interpreted that the Banyumas people do not stand idly by, are perseverance in achieving their ideals and defending them, and are not afraid to suffer and face life's problems. Therefore the Banyumas proverbs is an important asset in relation to the spirit of nationality; since by that spirit, Indonesian people will soon reach their goals. Cablaka, a local Banyumas terminology meaning 'as the way it is', historically and nationalistically described the spirit of Indonesian heroes. Therefore, it is highly expected that the next generation can inherit a simple, humble, honest and decisive soul in order to defend the nation and state of Indonesia.

Character and spirit in the personal figure of Banyumas People, the figure of Bawor, has become the character identification of Banyumas people, which makes this figure the mascot of Banyumas. Bawor's body shape is similar to Semar's with his almost round body shape. Bawor's head was big (bkoak), his forehead was wide (nonong), was stocky with bulging navel, his voice was loud and heavy. However, in every appearance he always became a respected figure and his opinion was trusted by his younger siblings; Gareng and Petruk. Bawor is a fictional character only existed in Banyumas. The plays of the gagrak Banyumas, often portrayed Bawor's tricky style in trying to find a solution to end the gara-gara (part of the scenes of a leather puppet show) with a happy ending. So Bawor's intelligence is packaged in a semblothongan (a direct language, bold, unfiltered style) or dablongan style. So, he was trusted by his brothers even by his masters.

In the book Banyumas: Sejarah, Budaya dan Watak (Banyumas: History, Culture and Character) explained that Bawor has following description of character: patient and grateful hearted, original in daily life, gentleman (honest, good personality, tolerant, harmonious, helpful, put the interests of others above own), deft, and cablaka (a straightforward character owned by Banyumas people toward anything happens surrounding them by saying it boldly/frankly. (Budiono Herusatoto, 2008: 195).

In connection with Bawor's character there are several Bawor's characteristics which can be associated to the character of Banyumas people in general which are reflected in the proverbs that exist around Banyumas as follows:

\section{a. Patient}

(1) Turu Pitik, meaning sleep the way a chicken sleeps that always wakes up every few minutes; which means if someone wants to achieve something he must fight the laziness. (2) Kaya nyekel welut (like holding an eel), meaning something that is hard to get and needs patience to achieve it. The proverbs gives influence on the attitude of someone's persistence to be patient in achieving goals. (3) Madang Longan Turu Longan, meaning less eat less sleep. This is a suggestion for the Javanese who want to be unpretentious. Javanese people are encouraged to eat and sleep less if they want to succeed. (4) Ndeleng githoke dewek, meaning that people should do introspection before saying or deciding something. Obviously it's impossible for us to look at one's own back even if one uses a mirror to do so. This expression can be used to reprimand or advise, but it is commonly used when talking behind one's back: "Ana wong koh ora ndeleng githoke dhewek" (How could someone judge others without judging himself?). 


\section{b. Gentlemanlike}

(1) Wateke watu atos, wateke kleyang nglayan, this proverbs has the meaning that people who are steadfast in their personality are not easily influenced by others. Conversely people who falter their personality are easily influenced by others. (2) Diobong ora kobong, disiram ora teles, which means nothing happens. The real meaning is to defer by prioritizing the interests of others rather than his own; something that is difficult to achieve at this moment. Giving in does not always mean losing, but doing something that makes the situation more controlled. Let oneself be hurt, but surely one day the pain will be cured and replaced with happiness. If here is poison, there must also be antidotes, even though it is sometimes difficult to get. What a beautiful turbulent life, if we decorate it with a sense of giving up. (3) Enyong Langka Rika Ora Rame. Enyong means "I", while rika means "you". The Banyumas society are accustomed to living in harmony, living as social beings, they are not happy to live as individualists. So, they feel discomfort when doing things individually. It is like "I" cannot do something alone without "you". So, togetherness ig something important. To foster a sense of brotherhood and kinship, the relationship between citizens to support the spirit of mutual cooperation is also a principle in the pattern of kinship carried out by the Banyumas society. The manifestation of mutual cooperation is a concept of cooperation that is upheld; this is very familiar with the life of agrarian farmers. People in Banyumas in their survival always prioritize harmony and togetherness. In principle, family and mutual cooperation take precedence, all burdens are shared equally among the society members. This principle is still held firmly as a series of lives that help each other with fellow citizens and families.

\section{c. Cekatan}

Kebat liwat, pincang sikile (haste makes waste) proverbs that bears hurrying will result in poor endings. This proverb is often used to advise others to take action or make decisions carefully because rushing through things causes errors, resulting in time, efforts, resources, etc. being wasted.Usually proverbs have special or symbolic meanings. The implicit meaning contained in a proverb is related to human attitudes and treatments which are described by various situations relating to natural surroundings such as objects, animals, and plants for the purpose of teaching or reprimand in a polite and refined manner. (1) Sikil dadi endas, endas dadi sikil, meaning people who work hard wholeheartedly and spiritually. This proverb is often used to describe someone working in earnest and full of enthusiasm. (2) Atak-itik ora gelem meneng, is used to describe someone who cannot standstill and always busy himself with activities. In a broader sense, this proverbs is more about hard work character that exists in the Banyumas society who

upholds the spirit of hard work.

\section{d. Cablaka}

The Banyumas proverbs that reflects behavior (character) becomes the character of the society as a motivation for nationalism, for example blakasuta; 'honest or not a made up'. That expression is expected from all leaders who are always honest in the interests of the people. Therefore, blakasuta's behavior of a leader will motivate the progress of various interests of the Indonesian people. Then, (1) Kaya rai gedeg, which describes someone who does not have shame or in a specific sense is more about high self-esteem, so it tends to be frank of all speech and behavior. (2) Ora weruh lor kidule "(out of the blue/from nowhere). This proverbs is often used to describe someone who interferes in a problem without knowing the essence of the problem. (3) Criwis cawis, which much talk much action or someone who is "criwis cawis" is someone who even though says a lot; always comments on every single 
thing, he is also capable and willing to do things right. Even he wants to solve it himself since he feels others are too slow. "Criwis cawis" people may be pleasant-unpleasant people. In the end everyone will accept his presence happily, even felt entertained and helped.

The use of Banyumas proverbs containing local wisdom due to aesthetic demands (the demand for the beauty of language). The use of Banyumas language is often spiced with the expression of Banyumas proverbs in a unique and firm language. Such methods are often termed as cablaka "as the way it is" and the language is called basa ngapak (ngapak language). Therefore, if the speaker of such language has not been able to reach the ngapak degree, he is considered not having the ngapak languange competence and proficiency; he is not yet a Banyumas person. There is also a proverb which states adoh ratu cedhek watu means the Banyumas society is far from the palace, unlike the people of Jogja and Solo, the Banyumas are closer to nature, a hard life. The people of Banyumas are rooted in a society where there is no caste.

Most Banyumas people claim to be like Bawor because of the philosophy of his nature and attitude. This, among others, was formed by factors such as adoh ratu cedhek watu, which means far from the palace social order, only knows hard natural life order. Just speak with Javanese kluthuk (unpretentious, original ancient), sing pating mblekuthuk (exchanging hard words like the sound of boiling water). Lageyane, anggeren kumpul toli bleketupuk (once the fellow Banyumas gathered they then pleasantly involved in talking without paying attention to the surroundings). There is no more unggah-ungguh (politness)in such situation.

\section{Conclusion}

From the results of this study it can be concluded that the Java-Banyumas proverbs reflecting behavior (character) is symbolized in Bawor's character, namely (1) Sabar lan nrima, (Be patient and grateful hearted) take the lif the way it is. (2) Gentlemanlike (honest, good personality, tolerant) harmonious, helpful, put others interests above his own. (3) Cacutan (Deft). (4) Cablaka, a straightforward character owned by Banyumas people toward anything happens surrounding them by saying it boldly/frankly.

\section{References}

[1] Ahimsa-Putra, H. S. Patron \& Klien di Sulawesi Selatan: Sebuah Kajian Fungsional Struktural. Yogyakarta: Kepel Press. 2007

[2] Bernard, April and Adonis Diaz Fernandez. "Yoruba proverbs as cultural metaphor for understanding management in the Caribbean". International Journal of Cross Cultural Management.Vol 12(3) 329-338. 2012. DOI: 10.1177/1470595812440154

[3] Jha, Sadan. "Dak Vachan: Proverbial Wisdom from Mithila, Bihar". History and Sociology of South Asia 8(1) 35-58. 2014. DOI: 10.1177/2230807513506628.

[4] Herusatoto, Budiono. Banyumas, Sejarah, Budaya, Bahasa, dan Watak. Yogyakarta: LKIS Yogyakarta. 2008.

[5] Koentjaraningrat.. Kebudayaan Jawa. Jakarta: Balai Pustaka. 2009

[6] Kridalaksana, Harimurti. Kamus Linguistik. Jakarta: PT Gramedia Pustaka Utama. 2001

[7] Moleong, Lexy J. Metode Penelitian Kualitatif. Bandung: Remaja Rosdakarya. 1993. 
[8] Nurgiyantoro, Burhan. 2002. Teori Pengkajian Fiksi. Yogyakarta: Gadjah Mada University Press.

[9] Pluger Chris. "Translating New Testament Proverb-Like Sayings in the Style of Local Proverbs". United Bible Societies. Vol. 66(3) 324-345. 2015. DOI: 10.1177/2051677015610110.

[10] Spradley, James P. Metode Etnografi. Yogyakarta : Tiara Wacana Yogya. 1997.

[11] Subroto, Edi. Pengantar Metoda Penelitian Linguistik Struktural. Surakarta:Sebelas Maret University Press. 1992.

[12] Sutopo. Metodologi Penelitian Kualitatif. Surakarta: UNS. 2006. 